Editorial

\title{
Is it Possible to Use Kidneys with Small Renal Masses for Transplant? A New Strategy to Face Kidney Graft Shortage for Transplantation in Ibero-America
}

\section{¿Es posible utilizar riñones con masas renales pequeñas para trasplante? Una nueva estrategia para afrontar la escasez de injertos renales para trasplante en Iberoamérica}

\author{
David Andrés Castañeda-Millán, MD, MSc ${ }^{1}$ Herney Andrés García-Perdomo, MD, MSc, EdD, PhD, FACS ${ }^{2}$ \\ Antonio Alcaraz, MD, PhD ${ }^{3}$ \\ ${ }^{1}$ Urology Unit. Department of Surgery. Hospital Universitario \\ Nacional de Colombia. Bogotá, Colombia \\ 2 Division of Urology. Department of Surgery. School of Medicine. \\ UROGIV Research Group. Universidad del Valle. Cali, Colombia \\ ${ }^{3}$ Urology and Kidney Transplantation Department. Hospital Clinic de \\ Barcelona. University of Barcelona. Barcelona, Spain \\ Urol Colomb 2021;30:89-90.
}

Kidney transplantation (KTx) is the best treatment alternative for patients with end-stage renal disease (ESRD) ${ }^{1}$; however, there are many barriers to obtaining a KTx worldwide. One of the main barriers is the scarcity of kidney grafts from cadaveric donors. ${ }^{2}$ Furthermore, in many Latin American countries, organ donation rates (from brain death donors) have stabilized during the last decade and do not meet the social needs for KTx. ${ }^{3}$ Specifically, in Colombia, organ donation rates have not grown despite some recent legislative initiatives (implementation of opt-out organ donation system $)^{4}$ and there are still no protocols and regulations for donation after cardiac death. Currently, it is estimated that approximately 3000 people on the waiting list for KTx. ${ }^{5}$

The scarcity of kidney grafts for transplantation is a global issue. Currently, there are many ways to mitigate its impact on the KTx waiting list population: promoting kidney living donors programs (including paired kidney donation), implementing protocols for donation after cardiac death, and increasing the use of expanded criteria donors and kidney grafts with some, so called, marginal conditions (acute kidney injury, elderly donors and small renal masses [SRMs]). The latter has proven to be a safe option for KTx after ex-vivo bench tumor excision based on the very low local, contralateral recurrence and metastatic rates.

Address for correspondence Herney Andrés García-Perdomo, MD MSc, EdD, PhD, FACS, Departamento de Cirugía/Urología, Escuela de Medicina, Universidad del Valle, Cali, Colombia

(e-mail: editorrevista@scu.org.co).
The most recent Spanish experience ${ }^{6}$ showed that these kidney grafts are acceptable for elderly patients ( $>60$ years) or patients with significant comorbidities. In this study, 13 kidney allografts with SRM (mean tumor size $<2 \mathrm{~cm}$ ) were transplanted. All kidney grafts underwent tumor excision during bench surgery with immediate pathologic analysis to assess negative surgical margins. The most common tumoral type was clear renal cell carcinoma (RCC), and all tumors had low histological grade (Furhman I and II). All KTx recipients remained free of local tumor recurrence or metastasis, having a $70 \%$ graft survival at an eight-year follow-up. Recently, Cristea et al. ${ }^{7}$ described and summarized the most robust world experience: a total of 147 kidneys with SRMs were transplanted until 2020 (81\% RCCs). There were only two recurrences (1.4\%) with a graft survival at one-year follow-up of $95 \%$. The postoperative complications included urine leakage (4.5\%), bleeding and re-operation (1.8\%), and arteriovenous fistulae or pseudoaneurysm (1.8\%).

Similarly, Hevia et al. ${ }^{8}$ described a $95.6 \%$ overall graft survival rate and a $100 \%$ recurrence-free survival rate at a five-year follow-up. The mean tumor size was $2 \mathrm{~cm}$. There are also similar experiences in Chinese and Australian groups: transplanted kidney grafts with SRMs, showing similar overall and graft survival and complications; and a very low local recurrence rate. ${ }^{9,10}$
(C) 2021. Sociedad Colombiana de Urología. All rights reserved. This is an open access article published by Thieme under the terms of the Creative Commons Attribution-NonDerivative-NonCommercial-License, permitting copying and reproduction so long as the original work is given appropriate credit. Contents may not be used for commercial purposes, or adapted, remixed, transformed or built upon. (https://creativecommons.org/ licenses/by-nc-nd/4.0/)

Thieme Revinter Publicações Ltda., Rua do Matoso 170, Rio de Janeiro, RJ, CEP 20270-135, Brazil 
When considering the use of kidneys with a SRM for transplant, it is critical to understand that the benefits outweigh the risks. Most importantly, clinicians must inform patients and families about improving survival and preventing from remaining in dialysis (as the annual mortality rate of patients who are submitted to it is at $10 \%$ ), while having low risk of local recurrence or distant metastasis (never reported but there is a chance).

The use of kidney grafts with SRMs seems to be a viable alternative to mitigate the shortage of organs for transplantation. The ideal KTx recipient for this type of kidney graft is a wellinformed dialysis patient $>60$ years old, with multiple comorbidities and relatively short life expectancy. The outcomes of KTx with this type of graft are promising and can undoubtedly improve the quality of life and life expectancy of appropriately selected patients. However, this clinical transplant strategy requires a strict clinical follow-up and possibly some adjustments to the standard immunosuppressive regimens. ${ }^{11}$

\section{References}

1 Wang JH, Skeans MA, Israni AK. Current status of kidney transplant outcomes: Dying to survive. Adv Chronic Kidney Dis 2016; 23(05):281-286. Doi: 10.1053/j.ackd.2016.07.001

2 Stephan A. Organ Shortage: Can we decrease the demand? Exp Clin Transplant 2017;15(Suppl 1):6-9. Doi: 10.6002/ect.mesot2016.L27

3 World Health Organization - Global observatory on Donation and Transplantation. International Report on Organ Donation and Transplantation Activities Executive summary 2017. Accessed
May 2021 from: http://www.transplant-observatory.org/download/2017-activity-data-report/

4 Gómez-Aldana A, Tapias M, Rosselli D. Opt-out in kidney transplantation rates: the Colombian experience. Kidney Int 2020;97 (06):1299. Doi: 10.1016/j.kint.2020.02.009

5 Instituto Nacional de Salud - Red de Donación y Trasplantes. Informe ejecutivo Red de Donación y Trasplantes de Colombia 2019. Accessed May 2021 in https://www.ins.gov.co/Direcciones/ RedesSaludPublica/DonacionOrganosYTejidos/Estadisticas/Informe-Ejecutivo-Red-Donaci\%C3\%B3n-y-Trasplantes-2019.pdf

6 Musquera M, Sierra A, Diekmann F, et al. Increasing kidney grafts for transplantation. World J Urol 2020; [Epub ahead off print]. Doi: $10.1007 /$ s00345-020-03463-x

7 Cristea O, Warren J, Blew B, Rowe N. Transplanting kidneys from donors with small renal masses - a strategy to expand the donor pool. Can Urol Assoc J 2020;14(01):E32-E38. Doi: 10.5489/cuaj.5926

8 Hevia V, Hassan Zakri R, Fraser Taylor C, et al. Effectiveness and Harms of Using Kidneys with Small Renal Tumors from Deceased or Living Donors as a Source of Renal Transplantation: A Systematic Review. Eur Urol Focus 2019;5(03):508-517. Doi: 10.1016/j. euf.2018.01.018

9 Wang X, Zhang X, Men T, et al. Kidneys with small renal cell carcinoma used in transplantation after ex vivo partial nephrectomy. Transplant Proc 2018;50(01):48-52. Doi: 10.1016/j.transproceed.2017.12.006

10 Nicol DL, Preston JM, Wall DR, et al. Kidneys from patients with small renal tumours: a novel source of kidneys for transplantation. BJU Int 2008;102(02):188-192, discussion 192-193. Doi: 10.1111/j.1464-410X.2008.07562.x

11 Frascà GM, D'Errico A, Malvi D, et al. Transplantation of kidneys with tumors. J Nephrol 2016;29(02):163-168. Doi: 10.1007/ s40620-015-0249-2 